\title{
Informality and the context of reception in South Africa's new immigrant destinations
}

Nik Theodore, Anmar Pretorius, Derick Blaauw and Catherina Schenck

\begin{abstract}
This study examines the context of reception for Zimbabwean migrants who are engaged in South Africa's informal economy. It seeks to contribute to two areas of migration scholarship: (a) the emergence of new immigrant destinations in the global South and (b) the role of the informal economy in shaping the context of reception for migrants in new gateway cities. Through surveys of Zimbabwean day labourers in Tshwane (formerly Pretoria), we document the poverty and the food and housing insecurity these migrants and their dependents endure resulting from underemployment in the informal economy. The analysis presented here suggests that although it has received little attention from migration scholars, the informal economy can play a significant role in shaping the context of reception for immigrants in the new gateway cities of the global South. In many destination countries, the informal economy absorbs large numbers of migrants, making it an important, if flawed, source of employment, earnings, and remittances. With increasing levels of migration to major cities, the informal economy has become a key arena of migrant incorporation, with far-reaching implications for lives and livelihoods.
\end{abstract}

\section{Introduction: new immigrant destinations.}

The global map of migration is changing. It is estimated that in 2015, approximately 244 million persons were international migrants, an increase of more than $40 \%$ since 2000 (United Nations Department of Economic and Social Affairs, 2016). This unprecedented movement of people has contributed to a reconfiguration of the spatial patterns of migration. New gateways are opening as migrants search for economic opportunities or seek to escape armed conflict, political turmoil, and persecution. Major cities have been the locus of much of the new migration. The twin processes of migration and urbanisation, which in many parts of the world have become mutually reinforcing, have led to the pluralisation of new immigrant destinations (NIDs) and in some cases, contributed to the explosive growth of cities, particularly in the global South (International Organization for Migration, 2015; Price \& Benton-Short, 2007).

Through an examination of the intersection of migration, urbanisation, and informalisation in Tshwane, South Africa, this paper seeks to contribute to the literature on NIDs in the global South. We adopt this perspective for several reasons. First, a number of South African cities are among the new gateways for international migration that have developed over the last 2 
decades. Though the country has a long history of international labour migration, much of it based in circular migration through the apartheid-era foreign-worker programs that provided cheap labour to the mining sector, a new round of migration has intensified since the end of apartheid (Crush, 2011; Maharaj \& Moodley, 2000; Zuberi \& Sibanda, 2004). South Africa is now the principal destination for migrants from Southern Africa Development Community countries (Nshimbi \& Fioramonti, 2014).

Second, recent population movements from neighbouring states have been urbanising, and there are signs that rather than being temporary or circular, this migration might be more permanent than the labour migration of the past (Crush, Chikanda, \& Tawodzera, 2012). In this paper, we situate our analysis in the city of Tshwane (formerly known as Pretoria), which we characterise as one of South Africa's NIDs. Tshwane is the fifth largest metropolitan area in South Africa and the third largest in Gauteng province. The migration of foreign nationals to South Africa has been concentrated in Gauteng province, which is estimated to have a larger foreign-born population than all other provinces combined (Meny-Gibert \& Chiumia, 2016). Major cities have been the locus of most of this migration, and in Gauteng province, in-migration is overwhelmingly concentrated in the Johannesburg, Ekurhuleni, and Tshwane (Pieterse, 2015).

Third, the changing spatial dynamics of migrant settlement have drawn the attention of migration scholars, and there is a growing literature that examines the context of reception in NIDs (see Janská, Čermák, \& Wright, 2014; Li, 2012; Maharaj \& Moodley, 2000; Nawyn, 2016; Winders, 2014; Zúñiga \& Hernández-León, 2005). It is generally understood that there are multiple drivers of population movements to regions that previously have seen little in-migration, and that the promise of economic opportunity ranks among the most important. Research has also found that the context of reception in NIDs can figure prominently in the adverse incorporation of migrants, especially in areas where employment opportunities are constrained by discrimination or by tight labour markets, where local policy actors are hostile to the interests of recent immigrants, where xenophobia among residents is pervasive, or where the institutional infrastructure necessary for successful immigrant incorporation is underdeveloped (see Glick Schiller \& Çağlar, 2009; Marrow, 2011; Phillips \& Robinson, 2015; Samers, 2010; Visser, 2017). To date, however, the research literature examining patterns of South-South migration only gestures towards these issues, despite evidence that migration between low- and middle-income countries accounts for a substantial share of total global migration (International Organization for Migration, 2013).

Though rarely investigated in the academic literature on international migration, the emergence of new gateway destinations in the global South raises important questions about the nature of migrants' livelihood strategies in destination countries. In many parts of sub-Saharan Africa, for example, migrants resort to employment in the informal economy because opportunities in the "mainstream" economy are foreclosed, and they seek refuge in informal settlements because adequate housing simply is not available to them. Without question, these "contextual factors" shape migrants' lived experiences, certainly in the short term but perhaps over the long run as well. New immigrant gateways often lack functional 
institutional infrastructures to ensure the successful incorporation of migrants into the fabric of economic and social life, and as a result, adverse experiences in these sites of settlement can negatively affect the trajectories of migrants' lives and livelihoods. For some, new economic opportunities may emerge within the informal spaces of migrant incorporation, whereas, for others, the prospects of economic advancement may be highly constrained by inhospitable conditions in local economies (see Crush, Chikanda, \& Skinner, 2015; Myroniuk \& Vearey, 2014; Simone, 2003). These outcomes are contingent on a range of factors and thus are open to empirical investigation.

Many recent migrants to South Africa have turned to the informal economy as a means for securing their livelihoods (see Crush, Chikanda, \& Skinner, 2015), and conditions in day labour markets therefore can be seen as an important element of the context of reception for migrant workers. Through an analysis of migrant working conditions in day labour markets, this paper seeks to contribute to the literature on South-South migration and the emergence of NIDs outside the United States and Europe. The next section presents a brief history of labour migration in the post-apartheid period, with a focus on Zimbabwean migration to South Africa. This is followed by an examination of what we term the informality-migration nexus and the evolving linkages between unauthorised immigration and economic informality. We then present the methodology used for conducting surveys of day labourers, and we frame the research questions guiding this investigation. Survey data are presented and analysed in the following section, with a focus on the determinants of wages and earnings, as well as risks arising from food insecurity, housing insecurity, and rising xenophobic violence directed at migrants in the informal economy. We end with some concluding remarks.

2 Labour migration to South Africa after Apartheid. In some respects, South Africa might not fit neatly within the received definition of a "new immigrant destination." With its long history of labour migration that was tightly governed through a regime of contract-worker programs, it can be argued that South Africa should not be considered a site of "new" immigration flows. On the other hand, as we will argue following Crush et al. (2012), the characteristics of migration to the country have fundamentally changed, marking the current phase of immigration as distinct from that of earlier eras.

One of the cornerstones of apartheid-era employment policies was an extensive migrant labour system that supplied contract labour from neighbouring countries to mining operations within South Africa. Bilateral agreements between South Africa and Botswana, Lesotho, Malawi, Mozambique, and Swaziland created mechanisms for regularising the recruitment of an exploitable migrant labour pool that could be employed on a short-term basis with the requirement that they be repatriated within 2 years. In apartheid's waning years, the employment of migrant workers in sectors other than mining was governed by the Aliens Control Act No. 96 of 1991, which enshrined a labour market test into South African immigration policy. Under the Act, before hiring a migrant worker, an employer would have to demonstrate to the Department of Home Affairs that no South Africans were available to fill the job vacancy. The result was to essentially nullify opportunities for unskilled and 
semi-skilled migrant jobseekers to qualify for labour migration under the Act, which in turn led to "[t]emporary work, particularly in the urban areas, [being] driven underground" (Crush, 1999: 6) where employers could benefit from employing unauthorised immigrants at below-market rates and in jobs where violations of labour standards were common.

The end of apartheid and the inauguration of a democratically elected government brought about changes to South Africa's framework of immigration regulations. The Immigration Act No. 13 of 2002 opened new avenues for foreign nationals to become South African citizens and included provisions for temporary entry into the country for work, schooling, visiting family members, and other purposes. To be granted a work permit, an applicant's employer would be required to verify that (a) no South African could be identified with qualifications or skills and experience equivalent to those of the applicant, (b) the salary and conditions would be equal or above those for workers in similar positions, and (c) immigration authorities would be notified if the worker is no longer employed or employed in a different capacity. Other workers could be authorised to enter the country under a "corporate work permit," if their employer provided financial and legal guarantees stipulating that employees would abide by the country's immigration laws. Finally, the Act included provisions for special work permits that could be issued to especially qualified individuals who could provide skills that are in high demand by the South African economy. The provisions outlined above have been periodically revised through amendments to the Act, but the underlying concerns with ensuring clear net-positive impacts on the South African economy have remained unchanged. Because the Immigration Act, like the Aliens Act before it, privileges a labour market test to help determine a prospective migrants' eligibility to enter the country, for all intents and purposes, unskilled and lower skilled migrants have been prevented from securing work authorisation.

The end of apartheid substantially altered patterns of migration to South Africa, changes that still appear to be unfolding more than 2 decades later. Successive African National Congress governments have aggressively administered deportation policies, implemented a set of skills-based criteria for determining eligibility to enter the country to work, and pursued a "South Africa first" approach to labour migration, though not always in name (Crush, 2011; Trimikliniotis, Gordon, \& Zondo, 2008). The number of deportations from South Africa soared after the mid-1990s as the government sought to reduce the number of unauthorised immigrants and dissuade potential future undocumented immigrants from entering the country. Between 1990 and 2008, more than 3 million migrants were deported from South Africa, 90\% of whom were Zimbabweans and Mozambicans (Crush, 2011). It has been estimated that between 2004 and 2009, more than 700,000 Zimbabweans were deported (Solidarity Peace Trust, 2010). In 2007 alone, South Africa deported more than 200,000 Zimbabweans, with Zimbabwean nationals representing $65 \%$ of total deportees that year (Crush, Skinner et al., 2015). The Department of Home Affairs has since changed its record-keeping, so it is difficult to estimate the number of deportees by country of origin, but overall deportation levels remain high, with nearly 132,000 migrants deported during the 2013-2014 financial year (Department of Home 
Affairs, 2014). Immigration restrictions, including for a time reductions in the number of work permits issued, in large part have been a reaction to political pressures on the government to reduce job competition, an issue that has received considerable attention given South Africa's high levels of unemployment (Crush \& Williams, 2010). These policy initiatives have further restricted access to South African labour markets for unskilled or semi-skilled foreign nationals.

\section{1 | Contemporary migration from Zimbabwe}

For decades, immigration from Zimbabwe has accounted for the largest inflows of foreign-born workers into South Africa. In analysing contemporary population movements from Zimbabwe to South Africa, Crush et al. (2012) identified three distinct phases of migration. The first occurred in the 1990s, when the Mugabe government, bowing to pressure by the International Monetary Fund and the World Bank, implemented a series of structural-adjustment reforms. Taken at face value, these reforms were designed to attract foreign-direct investment, spur job creation, and secure medium- to long-term economic growth. These policy objectives, however, were not realised. Public-expenditure cuts, mounting public- and private-sector layoffs, and anaemic foreign investment in the Zimbabwean economy meant that low- and moderate-income residents suffered mounting material hardships (Bond \& Manyana, 2002; Potts with Mutambirwa, 1998). With livelihood options becoming increasingly restricted, many Zimbabweans sought opportunities through migration and/or through engagement in the informal economy (Crush et al., 2012: 8). Migration to South Africa rose sharply, especially among men in search of improved employment prospects. Migration was predominately circular and largely composed of the economically active members of Zimbabwean households who relocated to South Africa for short periods in an effort to increase household incomes.

The performance of Zimbabwe's economy, however, only worsened. The Mugabe government's ill-conceived land reforms that were initiated in the late 1990 s decimated the agricultural export sector and led to the large-scale displacement of farm labourers (Potts, 2011). In addition, widespread, politically motivated attacks against Mugabe's critics and political opponents caused further turmoil. By the early 2000s, a second phase of migration was underway as Zimbabweans fled the country to escape political hostilities and economic deprivation (see also Makina, 2007). This second phase ended around 2005 as a third began.

Based on a survey of migrants to Cape Town and Johannesburg, Crush et al. (2012: 21-26, 29) identify a third phase of Zimbabwean migration to South Africa beginning in the mid-200os and lasting at least until the early 2010s. This phase is distinctive in several respects:

- Approximately one-third of migrants had first relocated to another Southern Africa Development Community country prior to immigrating to South Africa.

- More than $40 \%$ of migrants to Cape Town (Western Cape Province) and Johannesburg (Gauteng province) initially settled in another province before moving to these cities.

- The proportion of young people, ages 15 to 24 , increased dramatically. 
- Approximately 35\% of migrants never held employment in Zimbabwe, and half were unemployed at the time they departed the country.

- The search for work was the leading motivation for migration cited by survey respondents (44\%), far outpacing "living conditions in Zimbabwe" (18\%).

- The dominant pattern of circular migration appears to have been broken.

South Africa's heightened immigration restrictions coincided with a rise in unauthorised migration, largely from Zimbabwe and other neighbouring countries, as well as a rise in employment in the informal economy by migrants whose entry into the formal sector is constrained. Crush (2011: 16) has summarised the situation as follows:

"The growth in irregular labour migration has been accompanied by growing informalisation of migrant labour employment. Before the 1990s, most labour migrants were employed in the formal sector. Since 1990, labour migrants have begun to work in the unregulated informal economy ...."

An illustration of this phenomenon can be seen in the findings of a 2010 survey of Zimbabwean migrants that found that $20 \%$ were working in the informal economy even though just $8 \%$ had been employed in the informal sector prior to emigrating from Zimbabwe (Crush et al., 2012).

\section{3 | The migration-informality nexus}

Recent research on the employment prospects of unauthorised migrants has found that the informal economy is an increasingly important source of economic opportunity and earnings. Though their participation in informalising segments of the economy may bring with it considerable hardships-in particular, low wages, limited access to government employment protections, and heightened exposure to substandard workplace conditions-it is now understood that in many price-competitive industries unauthorised immigrants have become the "workers of choice" for employers that are prepared to violate immigration and employment laws in an effort to hold down labour costs (see Bauder, 2006; Doussard, 2013; Johnson-Webb, 2002; Theodore, 2007). Often reluctant to contest violations of labour standards for fear of being identified by immigration-enforcement agents, undocumented immigrant workers may tolerate substandard employment because it can provide one of the few relatively accessible employment options available to them. High rates of deportation may have the unintended consequence of reinforcing their dependence on exploitative employers.

Undocumented migrants often find opportunities within the informal economy and informalising segments of local economies where workplace violations are prevalent because barriers to entry in these niches are low. The absence of effective government enforcement of labour standards creates a perverse set of incentives: it aligns with migrants' need to remain undetected while bolstering the resolve of certain employers to maintain profitability and market share by engaging in labour cost cutting and exploitation. As a result, labour standards in low-wage sectors of local economies deteriorate. 
Once they become informally employed, most migrants work for employers with close connections to the mainstream economy. These workers endure systemic instability in their employment arrangements because their employment contracts are unsecured, labour demand tends to be highly variable, and restrictive immigration policies loom in the background as a threat to migrants' livelihoods. With low and uncertain earnings and few alternatives outside of waged work, the bargaining position of workers in the informal economy erodes, further exacerbating the problems of labour market instability. Under these conditions, entire segments of local economies may become distorted, with wages governed largely by workers' vulnerabilities rather than by their skills, their productivity, or the requirements of humane social reproduction. There are indications that South Africa's day labour markets exhibit such distortions (Theodore et al., 2015) and that migrant day labourers may be especially impacted. It is to these questions that we now turn.

\section{4 | Methods, data, and research questions}

The data for this paper are drawn from a national survey of day labourers in South Africa, which was completed in 2008, as well as a follow-up survey in Tshwane that was completed in 2015. The countrywide investigation into the size and composition of day labour markets was administered across several phases, culminating in the first systematic, sampled survey of day labourers across South Africa. The 2015 Tshwane sample is part of a second round of surveying to examine changes in day labour markets. In this section, we provide a detailed description of the methodology used for sampling workers at informal hiring sites.

The initial countrywide survey began with a reconnaissance phase, and the information gathered was used to develop a procedure for estimating the number of day labourers in South Africa. At the outset of the project, all municipalities in South Africa, along with dozens of churches, non-governmental organisations, and social welfare organisations, as well as the Department of Labour, were contacted in early 2005 as a first step in determining in which South African towns and cities informal day labour markets had formed. Over the course of 2005 and 2006, members of the research team travelled throughout the country to perform in-person counts of the number of day labourers present at informal hiring sites. The results revealed that there were approximately 1,000 hiring sites across the country where no less than 45,000 day labourers stand in public spaces seeking work.

The next phase of the research focused on the sampling procedures and the design of the survey instrument. The sampling procedure was guided by the research strategies used in a national survey of day labourers in the USA (Valenzuela, Theodore, Meléndez, \& Gonzalez, 2006). The targeted research population included only those jobseekers who were looking for work at informal hiring sites. The capitals of all provinces and important population centres in the rural areas of South Africa were covered proportionally based on the number of day labourers present. Cluster sampling was undertaken according to the number of day labourers identified in each area, as well as the size of the various hiring sites, so as not to over-represent the rural day labourer population compared to that in urban areas, and the large hiring sites compared to the small sites and vice versa. 
A sample of between $5 \%$ and $10 \%$ was targeted for the survey in order to reduce the possibility of sampling error (De Vos, Strydom, Fouché, \& Delport, 2004), meaning that between 2,250 and 4,500 interviews would need to be completed nationwide. The survey instrument was designed in a multistage process, with the draft undergoing a pilot test before finalisation. The third phase involved training fieldworkers and conducting the interviews. A lead fieldworker, fluent in several of the official languages of South Africa, was employed and received extensive training in survey fieldwork. In addition to the lead investigators, students from the Department of Social Work at the University of South Africa comprised the fieldwork team. They, too, underwent an in-depth training process. The fieldwork began in February 2007 and was completed at the beginning of 2008. All questionnaires that were deemed to be unreadable or otherwise lacking in quality were discarded. The sample was then checked to make sure that proportionality in terms of regional distribution was maintained. In total, 3,830 surveys were analysed, representing $9 \%$ of the target population.

The 2015 survey in Tshwane followed a similar research protocol. In total, 335 day labourers were surveyed in 2007, and 290 were surveyed in 2015. Survey responses were collected from South Africa- born and foreign-born day labourers who were searching for work at informal hiring sites in Tshwane. For the 2007 survey, data on place of birth were collected for 335 day labourers, 129 (39\%) of whom were born in South Africa and 206 (61\%) of whom were born in another country. Of the foreign-born day labourers, 112 (54\%) emigrated from Zimbabwe, 72 (35\%) from Mozambique, 18 (9\%) from Lesotho, 3 from Namibia, and 1 from Swaziland. For the 2015 survey, data on place of birth were collected for 287 day labourers, 127 (44\%) of whom were born in South Africa and 160 (56\%) of whom were born in another country. Of the foreign born, the vast majority were from Zimbabwe (142 or 89\%), 10 (6\%) were born in Lesotho, 6 were born in Malawi, and just 2 were born in Mozambique.

The Zimbabwean day labourer workforce is mainly composed of men (88\%) who undertake a range of manual-labour jobs related to construction, gardening, and material moving. Seventeen Zimbabwean women were included in the Tshwane sample. They most often were employed as domestic workers, though several reported doing tiling and plastering work.

The survey analysis that follows focuses on the wages and earnings of day labourers, as well as the risks faced by this workforce. The analysis seeks to answer the following questions:

- What are the employment rates, wages, and earnings of migrant day labourers, and how do these compare to those of South Africa-born daylabourers?

- What demographic, human-capital, and labour-market factors influence earnings in informal employment?

- What risks and hardships do day labourers face in terms of their livelihoods and living arrangements? 
The aim of the analysis that follows is to shed new light on the contexts of reception encountered by migrant workers in the informal economy.

\section{Zimbabwean day labourers in Tshwane's restructuring economy}

The City of Tshwane is home to more than 2.92 million residents, an increase of $65 \%$ since 1996 (Parliament of the Republic of South Africa, 2014). The Tshwane economy has been expanding as well; by 2011, the municipality's growth rate was nearly $70 \%$ higher than the national average (City of Tshwane, 2013), and the municipality is now the second largest contributor to South Africa's gross domestic product (Parliament of the Republic of South Africa, 2014). Growing tourism, construction, and services sectors also contribute to the municipality's economic output. These latter sectors are among the key employers of lower skilled workers, including recent migrants.

Tshwane has an official unemployment rate in 2011 of $24.2 \%$, which though one of the lowest urban unemployment rates in South Africa, remains a high figure. Poverty rates are also high, with an official poverty rate of $27.9 \%$ (Parliament of the Republic of South Africa, 2014). Much of the poverty population is concentrated in economically disadvantaged areas, including the numerous informal settlements in the region. More than 104,000 households reside in an informal dwelling, a figure that has been on the rise, in large part, according to the municipality, because of increased migration to the city as jobseekers arrive to look for work (City of Tshwane, 2013).

Although the informal economy in South Africa is small relative to that of many other countries across Africa, it has been growing (International Labour Organisation, 2013), including its day labour market (Theodore et al., 2015). With little direct governmental support for unemployed workers in low-wage segments of the South African economy (Ebrahim, Leibbrandt, \& Woolard, 2015), out-of-work jobseekers must rely on family-support networks, means-tested social assistance, and employment in the informal economy for their livelihoods. However, the low wages and chronic employment instability that are associated with informal employment mean that participants in South Africa's day labour markets typically subsist on below-poverty-level earnings and face material hardships (Pretorius \& Blaauw, 2015; Theodore, Blaauw, Pretorius, \& Schenck, 2017).

The demographic composition of Tshwane day labour markets has experienced significant shifts in the last decade as foreign migrants, most of whom are undocumented (Blaauw, Pretorius, Schoeman, \& Schenck, 2012), have become an increasing proportion of the worforce. In 2004, migrants composed approximately $12 \%$ of the Tshwane day labour workforce (Blaauw, Louw, \& Schenck, 2006). By 2007, this figure had increased to 61\%, with Zimbabweans accounting for more than half of day labourers seeking work at informal hiring sites. Migrants composed $56 \%$ of Tshwane day labourers in 2015, 89\% of whom were from Zimbabwe. It appears, therefore, that the day labour workforce is increasingly composed of the "third wave" Zimbabwean migrants described by Crush and colleagues. This 
phase is especially notable because the search for work has emerged as the leading motivation for migration and because patterns of circular migration appear to have been broken.

Day labourers are hired to perform manual-labour tasks related to construction and gardening. In Tshwane, Zimbabwean immigrants are most often employed as assistants to bricklayers, painters, plumbers, and roofers, as well as to perform work as gardeners, movers, plasterers, and painters. Nearly $60 \%$ indicated that they had never held a full-time job. Of those who had been employed in a full-time position, previous employment in construction, service jobs such as security, and domestic work was common, and these jobs mainly were of short duration. By far, the most common reasons that the worker left a full- time job was related to a business closure or expired contract (57\%) followed by low pay (21\%). With few, if any, alternative employment options available, immigrant jobseekers turned to jobs in Tshwane's informal economy.

\subsection{Determinants of wages and earnings}

Wages across Tshwane's day labour market are low and insecure. Using the 2015 survey, we examine income levels from day labour and the key determinants of workers' wages and earnings. Zimbabwean day labourers report that they work, on average, just 1.2 days each week, despite searching for work at informal hiring sites an average of 5.4 days per week (nearly half of these jobseekers search for work 7 days a week). When they are able to secure employment, average wages were ZAR 27.81 (USD 1.97) per hour. ${ }^{1}$ The wage structure in day labour markets is compressed, ranging from ZAR 14.21 (USD 1.01) for site cleanup to ZAR 22.65 (USD 1.60) for gardening to 26.10 (USD 1.85) for painting. The main outlier within the wage distribution is tiling jobs, which pay ZAR 60.71 (USD 4.29) per hour, though respondents reported a low number of hours worked in this occupation.

Low wage rates and employment instability result in average weekly earnings from day labour of just ZAR 198.31 (USD 13.77). To explore the determinants of weekly earnings and hourly wage rates, cross-sectional regression analyses were conducted (Tables 1 and 2). The models are adaptations of the classical Mincerian earnings equation, and the explanatory variables are similar to those usually employed in studies of workers' wages, including key human-capital variables. We do note that questions have been raised regarding the impact of human-capital attributes on migrants' wages (Baldacci, Inglese, \& Strozza, 1999; Friedberg, 2000). However, whether this tendency occurs in informal employment must be tested, and if human- capital attributes are found to have only a minimal impact on incomes, this finding must be explained.

With no primary schooling as a basis, four dummy variables test for the significance of formal schooling in determining migrants' wages: primary school completed, some secondary school completed, secondary school completed (matriculation), and post-secondary school qualification. A dummy variable for vocational training completed is also included. The impact of previous formal employment is tested using dummy variables for previous employment in high-skilled and low-skilled jobs. Focusing on the specific activities that day 
labourers engage in, it is expected that those who hold highly skilled jobs should earn more and those performing less-skilled jobs.

The ability to communicate in the language of the host country has been found to raise immigrants' wages (Budría, de Ibarreta, \& Swedberg, 2017; Gao \& Smyth, 2011). A dummy variable therefore tests for the impact of fluency in Afrikaans. Bartley and Roberts (2006) highlight the importance of being hired repeatedly by the same employer in determining day labourers' wages. A dummy variable tests for the effect of being hired by the same employer more than three times. Research has shown that the labour market experience of international migrants in a host country is positively related to earnings (Borjas, Bronars, \& Trejo, 1992; LaLonde \& Topel, 1991). Therefore, the number of months that migrants were involved in day labouring in South Africa tests the impact of time working as a day labourer on wage rates and earnings.

We do not find a statistically significant relationship between weekly earnings and levels of formal schooling represented by dummy variables for primary school completed, some secondary school completed, secondary school completed (matriculation), post-secondary school qualification, or vocational training completed. The sign of the coefficient for previous employment in a high-skilled, formal-sector job was positive but not statistically significant. In addition, the number of day labour jobs performed in the last month did not exhibit a statistically significant impact on earnings. On the other hand, the factors that appeared to impact weekly earnings were reporting that one is often hired more than three times by the same employer (positive), being female (positive), performing a high-skilled day labour job in the previous month (positive), the number of months standing as day labourer (positive), speaking Afrikaans well (negative), and having one's most recent formal-sector employment in a low-skilled occupation (negative). These results are generally consistent with results of an hourly wage model (Table 2) and a monthly earnings model (not presented here). In the hourly wage model, the estimated signs of the coefficients for speaking Afrikaans well and recently being employed in a low-skilled occupation are the same as reported in the monthly model, although they are not statistically significant. 
TABLE 1 Determinants of weekly earnings of Zimbabwean day labourers in Tshwane, 2015

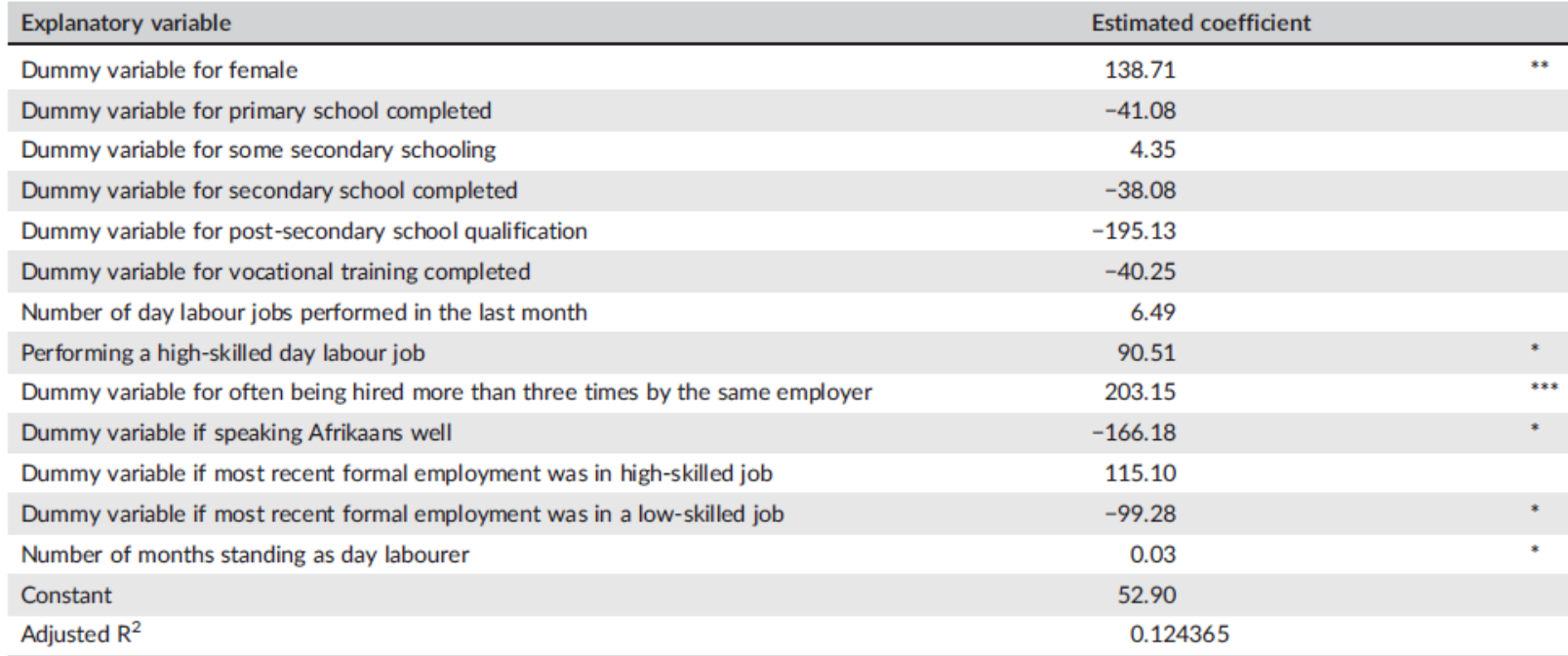

${ }^{* * *}$ Statistically significant at $1 \%$.

${ }^{* *}$ Statistically significant at $5 \%$.

${ }^{*}$ Statistically significant at $10 \%$.

TABLE 2 Determinants of hourly earnings of Zimbabwean day labourers in Tshwane, 2015

\begin{tabular}{|c|c|c|}
\hline Explanatory variable & Estimated coefficient & \\
\hline Dummy variable for female & 12.03 & $* * *$ \\
\hline Dummy variable for primary school completed & 14.24 & * \\
\hline Dummy variable for some secondary schooling & 7.14 & \\
\hline Dummy variable for secondary school completed & 7.14 & \\
\hline Dummy variable for post-secondary school qualification & 1.10 & \\
\hline Dummy variable for vocational training completed & 3.37 & \\
\hline Number of day labour jobs performed in the last month & -0.43 & \\
\hline Performing a high-skilled day labour job & 8.64 & $* *$ \\
\hline Dummy variable for often being hired more than three times by the same employer & 9.45 & $* *$ \\
\hline Dummy variable if speaking Afrikaans well & -9.78 & \\
\hline Dummy variable if most recent formal employment was in high-skilled job & 3.48 & \\
\hline Dummy variable if most recent formal employment was in a low-skilled job & -2.15 & \\
\hline Number of months standing as day labourer & 0.002 & $*$ \\
\hline Constant & -5.41 & \\
\hline Adjusted $\mathrm{R}^{2}$ & 0.052863 & \\
\hline
\end{tabular}

${ }^{* * *}$ Statistically significant at $1 \%$.

${ }^{* *}$ Statistically significant at $5 \%$.

*Statistically significant at $10 \%$.

We find a weak relationship between typical human-capital measures of educational attainment, vocational training qualifications, or previous employment experience in a high-skill formal-sector job. These results are at odds with human-capital theory that postulates that, ceteris paribus, income levels will rise with the level of education and training investments made by individuals. There are several explanations for these findings, which have implications for understanding employment outcomes in the informal economy. 
First, it is difficult for workers at informal hiring sites to make their skill sets legible to prospective employers. Because employers have limited means through which to assess worker skills, highly skilled day labourers are rarely able to distinguish themselves from less-skilled workers. When the use of skills differentiation as a means of securing higher wages and improved employment opportunities is impeded, wages scales become compressed (Theodore et al., 2015). The resulting downward wage pressures affect all day labourers regardless of their human-capital attributes because all workers at informal hiring sites must compete for the same limited number of jobs that are on offer each day.

Second, and relatedly, because informal labour markets are not regulated by strong institutional mechanisms or social norms that increase pay levels, wage rates are established by direct, face-to-face competition between workers. Because day labour markets are characterised by extraordinarily low employment rates-just $20.5 \%$ of all day labourers secured a job each day in the week prior to the survey-competition for employment is understandably intense which serves to maintain constant downward pressure on wages. Furthermore, individual workers have little recourse in terms of bargaining for higher wages. They of course may decline a job offer because the pay is too low. But with an oversupply of jobseekers, it is likely that employers will have a more-than-ample number of workers from which to select a temporary employee. With jobseekers regarded (and paid) as if they are a substitutable labour supply, wage rates flatten, in large part regardless of worker skills.

There are exceptions to these general observations. For those workers who indicate that they "often" have been hired by employers three or more times and therefore have had opportunities to demonstrate their skills and reliability, weekly earnings are higher and this effect is statistically significant. Having a large number of repeat employers both improves the regularity of work and its remuneration and therefore is something that day labourers seek to cultivate. Length of experience as a day labourer also seems to play a role. The estimated coefficients in both models suggest higher earnings for workers who have been involved in day labouring for more months (significant at the 10\% level).

In terms of the remaining variables, the positive effect on earnings of being a female appears to be driven by a small number of high-wage job assignments by women who secured employment as tilers and plasterers. The negative effect of having one's most recent formalsector job in a low-skill occupation was expected. Finally, the reason why Afrikaans-language proficiency is associated with lower weekly earnings is likely because the small number of Afrikaans-speaking Zimbabweans worked little during the week prior to the completion of the survey.

\subsection{Heightened risks: Food insecurity, inadequate housing, and xenophobia}

Given the low employment rates and meagre average weekly wages, it is little surprise that the typical monthly earnings of day labourers are low. Using weekly earnings and employment probabilities, we estimate that average monthly earnings of Zimbabwean day labourers in 
Tshwane are ZAR 785.76 (USD 55.60). The highly contingent nature of day labour and its associated low earnings levels contribute to heightened levels of food and housing insecurity for Zimbabwean migrants. This section examines these issues, which constitute two key elements of migrant day labourers' context of reception and the problem of group violence against migrants that appears to be increasing within informal settlements in Tshwane and other urban areas (Crush \& Ramachandran, 2015).

With low earnings levels, many Zimbabwean day labourers frequently face struggles meeting their daily requirements for food. More than half (52\%) reported that there were times in the previous month that there was no food to eat of any kind in their home because of lack of resources to obtain food, and 20\% reported that this occurred five or more times in the previous month. Similarly, 39\% reported that there were times in the previous month when someone in the house would go to sleep at night hungry because there was not enough food. These measures of extreme food insecurity are clear indicators of inadequate incomes from day labour and other sources, and they mirror findings of generalised food insecurity among Zimbabwean immigrants living in South African cities (Crush \& Tawodzera, 2016).

The residential pattern of Zimbabwean day labourers is highly dispersed, with the workforce spread across 42 neighbourhoods, townships, and informal settlements. One quarter (25\%) reported that they were residing in Mamelodi, a township outside of Pretoria that was established in 1953 by the government under apartheid, 13\% were residing in an informal settlement known as Plastic View, and $7 \%$ were residing in the township of Olievenhoutbosch. All three areas have witnessed a dramatic expansion of informal housing. More than $80 \%$ of Zimbabwean day labourers indicated that they are living in some form of informal dwelling. Living in a shack was most common response (58\%), followed by a backyard shed known as a Wendy house (19\%), sleeping outside on the street or bush area (4\%), and a shelter for the homeless (4\%). Just $17 \%$ reported residing in a formal housing structure. There are similarities between migrants' place of residence and that of South Africa-born day labourers, with 23\% residing in Mamelodi township and 8\% residing in Olievenhoutbosch township. South African day labourers were more likely to reside in a formal dwelling (32\%).

It has been suggested that competition for housing and economic opportunity among impoverished urban residents has contributed to the outbreaks of xenophobic violence against African immigrants that have occurred in South African cities and, in particular, within dozens of informal settlements located in these cities (Human Sciences Research Council, 2008). In their examination of the geographies of group violence against migrants, Crush and Ramachandran (2015) identified Mamelodi and Tembisa (the latter being the second most common area of residence for South Africa-born day labourers in Tshwane) as two sites in which multiple outbreaks of collective violence against immigrant shopkeepers has occurred. Tevera (2013) lists Olievenhoutbosch as a key site of xenophobic violence targeting residents of the Choba informal settlement located within its boundaries, whereas Madienyane (2013) identifies Plastic View as a site of collective violence against foreign nationals. It appears that within these principal areas of residence for immigrant 
day labourers in Tshwane, as in other areas where collective violence has occurred, a dangerous mix of (a) anti-immigrant sentiments, centring on the perception that most immigrants are in the country without authorisation; (b) fears that immigrant workers are depressing wage rates and "stealing" jobs; (c) claims that immigrant entrepreneurs are engaging in unfair competition; and (d) reports that foreigners are receiving preferential treatment in local housing markets, has led to reprisals against immigrants (Crush \& Ramachandran, 2015; Human Sciences Research Council, 2008). Moreover, there are indications that "levels of xenophobia are highest among self-employed South Africans in the informal economy" (Crush \& Ramachandran, 2015: 31), which suggests that complex dynamics are at play within the informally employed labour force. The result has been dramatically elevated risks to lives and livelihoods for migrant day labourers.

Faced with formidable conditions in this gateway city and an inadequate socioeconomic infrastructure for successful incorporation into urban life, many Zimbabwean migrants have turned to social networks to ease their settlement in Tshwane. More than half (59\%) indicated that they are part of a group of day labourers who help each other meet their daily needs for food, shelter, and employment. Of those who are part of self-help groups, $84 \%$ indicated that workers help each other with accessing food, $65 \%$ help each other find work, $27 \%$ provide loans to one another, and $17 \%$ assist with housing. Although some of these networks are grounded in day labourers' places of residence, it appears that they primarily form and are maintained at informal hiring sites. Together, these types of collective assistance constitute a regime of informal social protection based in an ethos of reciprocity (Bilecen \& Barglowski, 2015; see also Faist, Bilecen, Barglowksi, \& Sienkiewicz, 2015), and they are important ways that day labourers navigate an inhospitable environment within a NID.

\section{6 | Conclusion}

This paper has taken up Winders's (2014) call for more research into NIDs, with a particular focus on South-South migration to urban South Africa. Through the lens of informal day labour markets in Tshwane, we have examined the context of reception for Zimbabwean migrants and the challenges they face related to their participation in the informal economy. Tshwane provides a revealing and appropriate locale for this study. With its rapidly growing economy, which nevertheless exists side by side with high levels of poverty and unemployment, the metropolitan area has been the destination for large numbers of foreign nationals. Processes of urbanisation and the (often unrealized) promise of economic opportunity appear to be major drivers of Zimbabwean migration to Tshwane, and its status as a new immigrant gateway is now firmly established.

Successive phases of Zimbabwean migration to South Africa have resulted in large numbers of unauthorised immigrants relocating to urban areas and engaging in informal economic activities. Those who have turned to day labour as their primary means of generating an income have had to contend with low wages and unstable employment. This article has analysed dynamics within informal job markets and shown that earnings levels remain persistently low, in part because skill levels do not, by and large, drive wage rates in this 
segment of the economy. Rather, the oversupply of labour and the scarcity of employment opportunities it creates places sustained downward pressures on wages and earnings.

Poverty-level earnings in turn cause significant material hardships. Zimbabwean day labourers in South Africa endure high rates of food insecurity, and many reside in substandard dwellings located in informal settlements. To make matters worse, tensions between South Africans and migrant workers have erupted periodically, resulting in outbreaks of xenophobic violence targeting migrants living in informal settlements and working in the informal economy. Competition for jobs and housing has contributed to rising xenophobic anxieties, and it is unlikely that these will abate anytime soon.

The analysis presented here suggests that although it has received little attention from migration scholars, the informal economy can play a significant role in shaping the context of reception for immigrants in the new gateway cities of the global South. In many destination countries, the informal economy absorbs large numbers of migrants, making it an important, though flawed, source of employment, earnings, and remittances. Competition in this segment of the economy is intense, and with relatively low barriers to entry and increasing migration flows to major cities, the informal economy will be a key arena of migrant incorporation, with far-reaching implications for lives and livelihoods.

\section{Acknowledgements}

This research was supported through funding from the South African National Research Foundation.

\section{Endnotes}

1 The ZAR/USD rate used was the average for the November 2015, obtained from the South African Reserve Bank (2016) Selected Historical Rates accessed at: https://www.resbank.co.za/Research/Rates/Pages/SelectedHistoricalExchangeAndInterestRates .aspx.

\section{ORCID}

Nik Theodore http://orcid.org/oooo-0001-6629-779X

Derick Blaauw http://orcid.org/0000-0001-8750-4946

Catherina Schenck http://orcid.org/0000-0001-5299-5335 


\section{References}

Baldacci, E., Inglese, L., \& Strozza, S. (1999). Determinants of foreign workers' wages in two Italian regions with high illegal immigration. Labour, 13(3), 675-709.

Bartley, T., \& Roberts, W. T. (2006). Relational exploitation: The informal organization of day labor agencies. WorkingUsa, 9(1), 41-58.

Bauder, H. (2006). Labor movement: How migration regulates labor markets. Oxford: Oxford University Press.

Bilecen, B., \& Barglowski, K. (2015). On the assemblages of informal and formal transnational social protection. Population, Space and Place, 21(3), 203-214. https://doi.org/10.1002/psp.1897

Blaauw, D., Louw, H., \& Schenck, R. (2006). The employment history of day labourers in South Africa and the income they earn - A case study of day labourers in Pretoria. South African Journal of Economic and Management Sciences, NS, 9(4), 458-471.

Blaauw, P. F., Pretorius, A. M., Schoeman, C. H., \& Schenck, C. J. (2012). Explaining migrant wages: The case of Zimbabwean day labourers in South Africa. International Business \& Economics Research Journal, 11(1), 1333-1346.

Bond, P., \& Manyana, M. (2002). Zimbabwe's plunge: Exhausted nationalism, neoliberalism and the struggle for social justice (2nd ed.). Pietermaritzburg: University of Natal Press.

Borjas, G. J., Bronars, S. G., \& Trejo, S. J. (1992). Assimilation and the earnings of young internal migrants. The Review of Economics and Statistics, 74(1), 170-175.

Budría, S., de Ibarreta, C. M., \& Swedberg, P. (2017). The impact of host language proficiency across the immigrants' earning distribution in Spain. IZA Journal of Development and Migration., 7, 12.

City of Tshwane (2013). Draft 2013/14 IDP Review 28 March. Tshwane: City of Tshwane.

Crush, J. (1999). Fortress South Africa and the deconstruction of apartheid's migration regime. Geoforum, 30(1), 1-11.

Crush, J. (2011). Complex movements, confused responses: Labour migration in South Africa ()SAMP Policy Brief No. 25. Cape Town: Southern African Migration Programme.

Crush, J., Chikanda, A., \& Skinner, C. (2015). Mean streets: Migration, xenophobia and informality in South Africa. Cape Town: Southern African Migration Programme, African Centre for Cities, and International Development Research Centre.

Crush, J., Chikanda, A., \& Tawodzera, G. (2012). The third wave: Mixed migration from Zimbabwe to South Africa. Migration Policy Series No. 59. Cape Town: Southern African Migration Programme.

Crush, J., \& Ramachandran, S. (2015). Doing business with xenophobia. In J. Crush, A. Chikanda, \& C. Skinner (Eds.), Mean streets: Migration, xenophobia and informality in South Africa (pp. 25-59). Cape Town: Southern African Migration Programme, African Centre for Cities, and International Development Research Centre.

Crush, J., Skinner, C., \& Chikanda, A. (2015). Informal migrant entrepreneurship and inclusive growth in South Africa, Zimbabwe, and Mozambique Migration Policy Series no. 68. Cape Town: Southern African Migration Programme.

Crush, J., \& Tawodzera, G. (2016). The food insecurities of Zimbabwean migrants in urban South Africa. Cape Town: African Food Security Urban Network. 
Crush, J., \& Williams, V. (2010). Labour migration trends and policies in Southern Africa SAMP Policy Brief No. 23. Cape Town: Southern African Migration Programme.

De Vos, A. S., Strydom, H., Fouché, C. B., \& Delport, C. S. L. (2004). Research at the grass roots: For the social sciences and human service professions (2nd ed.). Pretoria: Van Schaik.

Department of Home Affairs. (2014). Annual report 2013/14. Pretoria: South Africa Department of Home Affairs.

Doussard, M. (2013). Degraded work: The struggle at the bottom of the labor market. Minneapolis, MN: University of Minnesota Press.

Ebrahim, A., Leibbrandt, M., \& Woolard, I. (2015). Strategies of the unemployed in South Africa: Does moving allow the unemployed to get ahead? SALDRU Working Paper Number 157. Cape Town: University of Cape Town.

Faist, T., Bilecen, B., Barglowksi, K., \& Sienkiewicz, J. J. (2015). Transnational social protection: Migrants' strategies and patterns of inequalities. Population, Space and Place, 21(3), 193-202. https://doi. org/10.1002/psp.1903

Friedberg, R. M. (2000). You can't take it with you? Immigrant assimilation and the portability of human capital. Journal of Labor Economics, 18(2), 221-251.

Gao, W., \& Smyth, R. (2011). Economic returns to speaking 'standard Mandarin' among migrants in China's urban labour market. Economics of Education Review, 30(2), 342352.

Glick Schiller, N., \& Çağlar, A. (2009). Towards a comparative theory of locality in migration studies: Migrant incorporation and city scale. Journal of Ethnic and Migration Studies, 35(2), 177-202.

Human Sciences Research Council (2008). Citizenship, violence and xenophobia in South Africa: Perceptions from South African communities. Pretoria: Human Sciences Research Council.

International Labour Organisation (2013). Women and men in the informal economy: A statistical picture. Geneva: ILO.

International Organization for Migration (2013). World Migration Report 2013-Migrant well-being and development. Geneva: IOM.

International Organization for Migration. (2015). World Migration Report 2015. Geneva: IOM.

Janská, E., Čermák, Z., \& Wright, R. (2014). New immigrant destinations in a new country of immigration: Settlement patterns of non-natives in the Czech Republic. Population, Space and Place, 2o(8), 680-693. https:// doi.org/10.1002/psp.1824

Johnson-Webb, K. D. (2002). Employer recruitment and Hispanic labor migration: North Carolina urban areas at the end of the millennium. The Professional Geographer, 54(3), 406-421.

LaLonde, R., \& Topel, R. (1991). Immigrants in the American labor market: Quality, assimilation, and distributional effects. The American Economic Review, 81(2), 297-302.

Li, M. (2012). Making a living at the interface of legality and illegality: Chinese migrant workers in Israel. International Migration, 50(2), 81-98.

Madienyane, D. (2013). The effects of vigilantism on the community of Diepsloot. Johannesburg: University of the Witwatersrand Graduate School of Public \& Development Management. 
Maharaj, B., \& Moodley, V. (2000). New African immigration to the Durban region. Canadian Journal of African Studies / Revue Canadienne des Études Africaines, 34(1), 149-160.

Makina, D. (2007). Profile of migrant Zimbabweans in South Africa: A pilot study. A Zimbabwe diaspora forum research report.

Marrow, H. (2011). New destination dreaming: Immigration, race, and legal status in the rural American South. Palo Alto, CA: Stanford University Press.

Meny-Gibert, S., \& Chiumia, S. (2016). Factsheet: Where do South Africa's international migrants come from? Africa Check, https://africacheck.org/factsheets/geography-migration/, accessed July 31, 2017.

Myroniuk, T. W., \& Vearey, J. (2014). Social capital and livelihoods in Johannesburg: Differential advantages and unexpected outcomes among foreign-born migrants, internal migrants, and long-term South African residents. International Migration Review, 48(1), 243-273.

Nawyn, S. J. (2016). New directions for research on migration in the global South. International Journal of Sociology, 46(3), 163-168.

Nshimbi, C. C., \& Fioramonti, L. (2014). The will to integrate: South Africa's responses to regional migration from the SADC region. African Development Review, 26(S1), 52-63.

Parliament of the Republic of South Africa (2014). City of Tshwane general and regional overview. Cape Town: Republic of South Africa.

Phillips, D., \& Robinson, D. (2015). Reflections on migration, community, and place. Population, Space and Place, 21(5), 409-420. https://doi. org/10.1002/psp.1911

Pieterse, A. (2015). Population movement in the Gauteng city region. Pretoria: CSIR.

Potts, D. (2011). Making a livelihood in (and beyond) the African city: The experience of Zimbabwe. Africa, 81(4), 588-605.

Potts, D., with Mutambirwa, C. (1998). "Basics are now a luxury": Perceptions of structural adjustment's impact on rural and urban areas in Zimbabwe. Environment and Urbanization, $10(1), 55-75$.

Pretorius, A., \& Blaauw, D. (2015). Getting to know the Amakwerre-kwerre: The socio-economic circumstances of Zimbabwean day labourers in South Africa. Ethnic and Racial Studies, $38(5), 808-823$.

Price, M., \& Benton-Short, L. (2007). Immigrants and world cities: From the hyper-diverse to the bypassed. GeoJournal, 68, 103-117.

Samers, M. (2010). Strange castle walls and courtyards: Explaining the political economy of undocumented immigration and undeclared employment. In G. Menz, \& A. Caviedes (Eds.), Labour migration in Europe (pp. 209-231). London: Palgrave Macmillan.

South African Reserve Bank. (2016). Selected historical rates, accessed on 22 February 2016 at:

https://www.resbank.co.za/Research/Rates/

Pages/SelectedHistoricalExchangeAndInterestRates.aspx.

Simone, AM. (2003). Moving towards uncertainty: Migration and the turbulence of African urban life. Conference on African Migration in Comparative Perspective, Johannesburg.

Solidarity Peace Trust. (2010). Desperate lives, twilight worlds: How a million Zimbabweans live without official sanction or sanctuary in South Africa. Johannesburg: Solidarity Peace Trust. 
Tevera, D. (2013). African migrants, xenophobia and urban violence in post- apartheid South Africa. Alternation, 7, 9-26.

Theodore, N. (2007). Closed borders, open markets: Day laborers' struggle for economic rights. In H. Leitner, J. Peck, \& E. Sheppard (Eds.), Contesting neoliberalism: Urban frontiers (pp. 250-265). New York: Guilford.

Theodore, N., Blaauw, D., Pretorius, A., \& Schenck, C. (2017). The socioeconomic incorporation of immigrant and native-born day labourers in Tshwane, South Africa. International Migration, 55(1), 142-156.

Theodore, N., Blaauw, D., Schenck, C., Valenzuela, A. Jr., Schoeman, C., \& Meléndez, E. J. (2015). Day labor, informality and vulnerability in the United States and South Africa. International Journal of Manpower, 36(6), 807-823.

Trimikliniotis, N., Gordon, S., \& Zondo, B. (2008). Globalisation and migrant labour in a 'rainbow nation': A fortress South Africa? Third World Quarterly, 29(7), 1323-1339.

United Nations Department of Economic and Social Affairs (2016). Trends in international migrant stock: The 2015 revision. Geneva: United Nations.

Valenzuela, A. Jr., Theodore, N., Meléndez, E., \& Gonzalez, A. L. (2006). On the corner: Day labor in the United States. Los Angeles and Chicago: UCLA Center for the Study of Urban Poverty and UIC Center for Urban Economic Development.

Visser, M. A. (2017). Reshaping migrant labour market geographies: Local regularisations and the informal economy. Population, Space and Place, 23(7), e2025. https://doi.org/10.1002/psp.2025

Winders, J. (2014). New immigrant destinations in global context. International Migration Review, 49(s1), s149-s179.

Zuberi, T., \& Sibanda, A. (2004). How do migrants fare in the post-apartheid South African labor market? International Migration Review, 38(4), 1462-1491.

Zúñiga, V., \& Hernández-León, R. (Eds) (2005). New destinations, Mexican immigration in the United States. New York: Russell Sage. 